\title{
Institutional conditions for Swedish metal production: a comparison of subsidies to metal mining and metal recycling
}

Nils Johansson, Joakim Krook and Mats Eklund

\section{Linköping University Post Print}

\section{Tweet}

N.B.: When citing this work, cite the original article.

Original Publication:

Nils Johansson, Joakim Krook and Mats Eklund, Institutional conditions for Swedish metal production: a comparison of subsidies to metal mining and metal recycling, 2014, Resources policy, Vol. 41, pp 72-82.

http://dx.doi.org/10.1016/j.resourpol.2014.04.001

Copyright: Elsevier

http://www.elsevier.com/

Postprint available at: Linköping University Electronic Press

http://urn.kb.se/resolve?urn=urn:nbn:se:liu:diva-97469 


\title{
Institutional conditions for Swedish metal production: a comparison of subsidies to metal mining and metal recycling
}

\author{
Nils Johansson ${ }_{a}$; Joakim Krook $a$, Mats Eklunda. \\ *Corresponding author: Department of Management and Engineering, Environmental Technology and Management, \\ Linköping University, SE-581 83 Linköping, Sweden. nils.johansson@liu.se, +46(0)13285629. \\ ${ }^{a}$ Department of Management and Engineering, Environmental Technology and Management, Linköping University, SE-581 \\ 83 Linköping, Sweden. joakim.krook@liu.se, mats.eklund@liu.se.
}

\section{Summary}

This article examines and contrasts the level of Swedish governmental subsidies to two different ways of producing metal: the metal recycling sector and the metal mining sector. In 2010, the metal mining sector was subsidized by $€ 40$ million and the metal recycling sector $€ 0.6$ million. If the exemption from landfill tax is considered a subsidy, the level of subsidization to the metal mining sector changes drastically to approximately $€ 4,000$ million. Regardless of how the concept "subsidy" is defined, the metal mining sector in total and per tonne of metal produced is fundamentally more highly subsidized than the metal recycling sector. The value added per tonne of metal produced for the metal recycling sector appears to be higher than for the metal mining sector. The current dominant trend in the Swedish mineral strategy is nevertheless to increase the level of subsidization to the metal mining sector.

Keywords: Subsidy, Recycling, Mining, Metal, Policy.

Highlights

- We compare subsidization of the metal recycling sector and the metal mining sector

- The metal mining sector is fundamentally more subsidized

- Per tonne of metal produced the recycling sector seems to add higher added value

- The current trend is to increase the level of subsidies to the mining industry

- Further stocks of secondary metals are available for recycling

\section{Introduction}

For industrialization at least four metals are crucial: iron for construction, aluminum for transport, lead in batteries and copper to conduct electricity. In advanced technologies additional metals are used, for example in circuit boards or hospital instruments. Virtually all metals in the periodic table are used, and those not in use today probably will be tomorrow (UNEP, 2010). Since many sectors rely on metals, concerns have arisen for decreasing accessibility of metals due to reasons such as increased consumption, political instability, depletion, trade barriers and environmental externalities.

To secure the supply of metals, the European Commission (2008) has identified three different strategies in its Raw Materials Initiative: "(1) ensuring a level-playing field in access to resources in third countries; (2) fostering a sustainable supply of raw materials from European sources; and (3) boosting resource efficiency and recycling". In the initiative, each member state is encouraged to develop a national mineral strategy. In February 2013, the Swedish government (2013) presented the first ever Swedish mineral strategy. In the national strategy, increased mining as well as recycling are stressed to meet the increased demand. 
In principle, metals in the form of a commodity can thus be produced in two distinct ways: through primary or secondary production, i.e., through mining or recycling. Both production methods as stated in the policies will remain important in order to meet future demand. By analyzing flows of metals, researchers (e.g. Lichtensteiger, 2002; Elshkaki et al., 2004; Spatari et al., 2005; Gordon et al. 2006; Müller et al., 2006; Halada et al., 2009) have demonstrated that the current accumulation of metals in the technosphere is comparable to the remaining known reserves in the Earth's crust. Previous research has also shown that the concentration and availability of metals varies above ground, just like below ground. For example, above-ground metals may be concentrated in steel girders as well as dissipated from old satellites in the form of debris orbiting around the Earth (Johansson et al., 2013). However, less attention has been given to the institutional conditions, which influence market prospect and the feasibility of an industrial sector, for primary and secondary metal production.

The role of the government and the institutional conditions for the mining sector have been discussed and mapped in theoretical studies (Bridge, 2014) as well as case studies (Grundnoff, 2012). The notion that primary metal production has more favorable institutional conditions than secondary metal production is in many ways an accepted fact. But this idea is based on general observations. For example, Ayres (1997) has demonstrated how energy-intensive primary production is favored by low taxes on extractive resources and energy while labor-intensive secondary production is disadvantaged by high taxes on labor. Comprehensive comparison of the institutional conditions between these two sectors, mapping the extent of political commitment both in total and in relation to the importance of the sectors, is largely lacking.

Institutional conditions may appear in many different forms: governmental policies such as instruments as well as targets. In this study, institutional conditions will be considered in the form of subsidies, i.e., direct or indirect government support to a specific sector, since this type of support is well-studied and has a developed methodology. By analyzing subsidies, political support can be quantified, which facilitates the comparison between the sectors. Subsidies are typically adopted to obtain objectives such as lower prices, to promote equality or emerging alternative markets, and to increase domestic supply, employment and growth (Lin, 1996; Schwartz and Clements, 1999).

Researchers have shown, however, that subsidies may have many negative and sometimes adverse side effects, such as impeding trade (Anderson and Martin, 2005), degrading the environment (Kleijn et al., 2001; Sterner, 2007; OECD, 2009), reducing economic efficiency (Tullock, 1975), establishing dependencies and lock-ins (Unruh, 2000; IEA et al., 2010), disrupting foreign markets, and increasing poverty and inequality (IFPRI, 2003; WRI, 207).

The point here is not to study the impact of metal subsidization. Instead, the aim of the paper is to quantify and contrast subsidies between two sectors producing essentially identical products, for example as previously done between the fossil-fuel sector and the renewable energy sector (e.g. IEA, 2011; GSI, 2010), thereby indicating political priorities and commitment. Hence, in this case the Swedish subsidies to the metal mining sector and the metal recycling sector are identified, quantified and contrasted in order to examine the level of government action to meet the policy goals of increased primary and secondary metal production. However, determining the level of subsidies is a political issue. Assessing the level of subsidies between two similar sectors nevertheless has the potential to reveal governmental priorities and thereby allow for further policy discussion. In this paper, only subsidies provided at the national level are examined.

\section{Method}

The concept of subsidy can be defined in different ways, depending on the purpose and perspective. Common to all definitions is that subsidies are a financial contribution or benefit from the state towards a specific type of production or consumption. Subsidies can further be understood narrowly, 
which could be the case in statistical compilations (e.g. The Swedish Board of Agriculture, 2013), including subsidies only in the form of direct transfers from government to industry. However, according to Bruce (1990), such an approach ignores the fact that governmental support may be implicit and that policies may have other or hidden intentions but nevertheless result in support for specific industries. Therefore, subsidies are commonly defined more broadly, to also include for example tax breaks and trade barriers (e.g. SCB, 2010; SEPA, 2012b). Subsidy analysis of trade or policy usually also embraces more implicit financial benefits such as research grants and uncollected or under-collected resource rents (e.g. Milazzo, 1998; Steenblik, 2002; OECD, 2010a; Yeo et al., 2010; IEEP, 2012; Gerasimchuk, 2012; Aarsnes \& Lindgren, 2012). An even broader definition, which is excluded in this analysis, would in the example of Pieters (1997) or Riedy (2007) include investment in general infrastructure or even the failure of government to act such as when it allows polluters to impose costs on others (see, e.g., Clements et al., 2013).

\subsection{The four types of subsidies}

Since the objective of this article is to analyze the level of governmental commitment, the definition and framework from policy analysis will be used. The framework for policy analysis (e.g. Steenblik, 2002; OECD, 2010a; Jones \& Steenblik, 2010) has been slightly modified to be better suited to metal production and four different types of subsidies are included: (i) direct transfers of funds; (ii) revenue forgone; (iii) indirect transfers of funds and services; and (iv) resource rent.

Funds transferred to a sector or industry can either be direct or conditional with obligations. Direct transfers are grants or capital contributions, for example to cover industrial losses, support exports or modernize an industry. Conditional transfers mean that they must be repaid unless certain conditions are fulfilled. Transfers of money are generally the most visible subsidy (Bruce, 1990; OECD, 2010a; Jones \& Steenblik, 2010), but require accuracy to avoid double counting. Therefore, transfers have primarily been sought in the Swedish national accounts rather than budget proposals.

Revenues forgone primarily include different tax anomalies such as concessions, exemptions or reductions (OECD, 2010a; Jones \& Steenblik, 2010). The value of the shortfall should, according to the WTO (1994), be estimated according to the extent to which government revenues are reduced, holding all other factors constant, i.e., the revenue forgone method. This method has become the most common comparative method to calculate tax shortfalls (OECD, 2010b; Jones \& Steenblik, 2010; Swedish Government, 2011) and will thus be used in this paper. The disadvantage of this method is that behavioral changes as a result of higher taxes are excluded, which, however, could be difficult to quantify. The presented shortfall is thus most likely higher than the potential tax revenue from removing the tax breaks. Another form of revenue forgone may be government loans that do not have to be repaid under certain circumstances, or debt relief.

Explicit transfers and services may include research grants that benefit a particular sector or indirect governmental support through, for example, their agencies towards specific sectors. Government may furthermore sell something to industry at below-market price or buy something from industry at above-market price. Another example of services is when the state guarantees loans or becomes the creditor of a bank loan (which reduces the interest rate). In these cases, the subsidy will be calculated by the price gap between the bargain price or rate and the market price or rate.

The fourth type of subsidy to be analyzed is uncollected or under-collected resource rent, which arises when governments undercharge enterprises for preferential access to domestic natural resources. However, it is difficult to define the benchmark of the resource rent and the exact economic value of the natural resource, i.e., what should be a justified resource rent? Therefore, the level of subsidy for this category will not be calculated. Instead, this section will primarily present how the sectors access the resources, i.e., the primary and secondary metals. 


\subsection{Data collection}

Information on subsidies has primarily been investigated by approaching the Swedish sector associations of secondary and primary metal production, i.e., Återvinningsindustrierna [the Swedish Recycling Industries Association] and Svemin respectively. They have been asked if any of the above four categories of subsidies exist, and if so their scope. To broaden the investigation and confirm the information from the sector associations, governmental agencies have been contacted. In order to identify direct transfer, Statistics Sweden (SCB) was contacted, since they are responsible for gathering information of the national accounts. In order to identify tax anomalies, the Swedish IRS (Skatteverket) was contacted, while concessional loans have been mapped by contacting governmental investment companies such as Inlandsinnovation and governmental lenders such as Almi.

Services and explicit transfers have been traced through contact and review of the annual reports of governmental agencies, primarily the Geological Survey of Sweden (SGU) and the Swedish Environmental Protection Agency (Naturvårdsverket). Research grants have been traced through contact with the major research funders in Sweden: Vetenskapsrådet, FORMAS, VINNOVA, NUTEK and MISTRA. However, since it is difficult to track all research projects and classify them accordingly, only major research programs related to metal recycling and metal mining have been included. The disadvantage of such an approach is that major research programs can include recycling and mining from a broader perspective, i.e., also include non-metals such as gravel, lime and clay. But since single research projects are excluded, the government funds to research in the mining and recycling field presented in the result are probably underestimated.

Some other government support schemes also embrace the whole mining sector. The extent of fuel credits may for example only be estimated for the whole Swedish mining sector, i.e., the extraction of all mineral rocks, since the Swedish IRS does not present the extent of tax reduction for subsectors. However, the Swedish fuel credit is only valid for fuel consumption in non-transport processes. Extracting metals highly embedded in rocks, deep in the crust, requires grinding as well as separation, all energy-intensive processes, while other rock minerals such as lime or gravel usually occur in open pits. The same also applies to the reported information support to prospectors, which includes all forms of mineral exploration, but where the overwhelming support goes to metal prospectors (Söderhielm, personal communication, 2013). The lack of adequate limitation means that the presented value of the tax reduction and the support to mineral prospecting is a high-end estimate.

\subsection{Delimitations}

Support of a general nature, for example based on the number of employees or size of the company, is excluded. This excludes for example the effects of current tax policy, where low energy taxes on electricity ${ }^{1}$ favor primary production since mining is energy intensive, while high taxes on labor are a disadvantage for secondary production since recycling is labor intensive (Ayres, 1997). Also, subsidies that cannot be connected to a specific sector, such as general infrastructure or research grants of a general nature for example for innovation will be excluded. Furthermore, only financial instruments towards the producer will be analyzed, since subsidies through consumers are mainly used in the energy and agricultural sectors (Steenblik, 2002). According to general practice (OECD, 2010a), the producers' gross revenue from subsidies are analyzed and not income, which would have included costs for receiving the subsidy. Costs to the government to administer the subsidy as well as inflation and interest rates are also excluded.

\footnotetext{
${ }^{1}$ In Sweden, industry pays 0.06 cent/Kwh, excluding VAT, in energy tax, which is the minimum permitted in the EU, while households pay 4 cents/kWh excluding VAT (SCS, 1994:1776). In the mining sector electricity is, for example, used to run the milling plant. The employment tax in Sweden is in general $31.42 \%$ of salary (SIRS, 2013).
} 
The results as well as other financial accounts have been converted from SEK to Euros $(€)^{2}$, to make the valuation more internationally viable. The results have been rounded to the nearest $€ 100,000$. The results are reported for the year 2010. The focus on a single year, however, excludes previous subsidies still in-use, in the form, for example, of former targeted infrastructure investments that the sector still benefits from. The risk of only a snapshot is furthermore that a mature sector, already established by state support, is compared with an emerging sector currently in need of state support and protection. However, both mining and recycling have a long history and thus can be considered comparable. In addition, to provide a more comprehensive picture and clarify any isolated events, subsidies granted during nearby years will also be reported and primarily presented in footnotes. The results will then be analyzed in line with other assessments of subsidies (e.g. Gerasimchuk, 2012; Aarsnes \& Lindgren, 2012; GSI, 2010) by contrasting the level of subsidization with the importance of the sector in terms of the size and added value of each sector.

This study covers the process from extracting the metals from the Earth's crust on the one hand, and the human built environment on the other, until the metals are sent to the smelter, as seen in Figure 1. This means for primary production that three different steps are relevant (prospecting, mining and milling), while for secondary production, collection, separation and fragmentation are included.

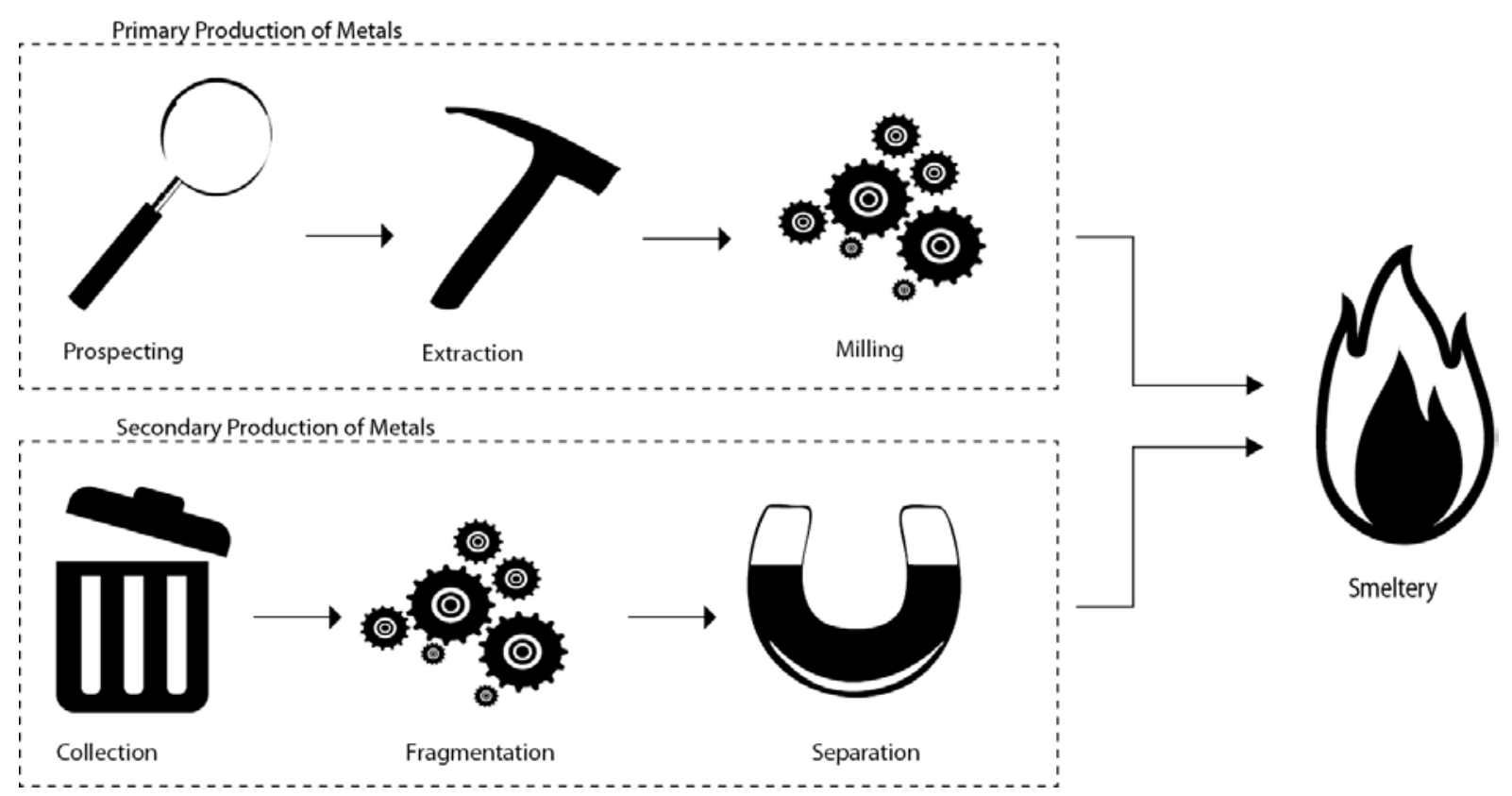

Figure 1. The system boundaries of this study start when the metals are extracted from the Earth's crust and the human built environment and end when the primary and secondary metals, respectively, are sent to the smelters.

\section{Results}

In recent years, the Swedish government has not transferred grants directly to either the Swedish metal mining sector or the metal recycling sector, as seen in Table 1 and 2. For example, in 2010 the Swedish state-owned mining company LKAB reported profits of $€ 1,400$ million (Johansson, 2011) and thus was not in need of any additional capital. In general, the mining sector is capital intensive, for example the average investment in 1998 to establish a mine was more than $€ 300$ million (EMJ, 1999), thus limited government loans and grants are seldom of any help to start up a private mine. Furthermore, Swedish export subsidies focus mainly on products and the manufacturing industry, for which insurance is available for failed business.

\footnotetext{
${ }^{2} € 100$ is in this paper equivalent to SEK 884 .
} 
However, in 2013 the venture capital company Norrskenet, which is one-third owned by the state through LKAB, invested $€ 18$ million in bonds to rescue the underfunded mining company Northland Resources (SVD, 2013). This bond is only a subsidy if the loan, for example, cannot be paid back, deviates from the payment plan, or if the interest rate, which was difficult to obtain, is different from the market rate ${ }^{3}$. On the other hand, in the mid-1990s, the Swedish Parliament allocated $€ 110$ million for a five-year investment program for transition to sustainable development (Swedish Government, 1995). In the year 2000, $€ 3$ million was transferred to the recycling sector, according to SCB (2010). However, the specific share of the metal recycling sector is unclear. The last transfer to the recycling sector was $€ 0.7$ million in the year 2003 (SCB, 2010).

Table 1. Subsidies identified and estimated for the Swedish recycling sector for the year 2010. The subcategories are presented in bold, while the actual subsidy is presented below each subcategory.

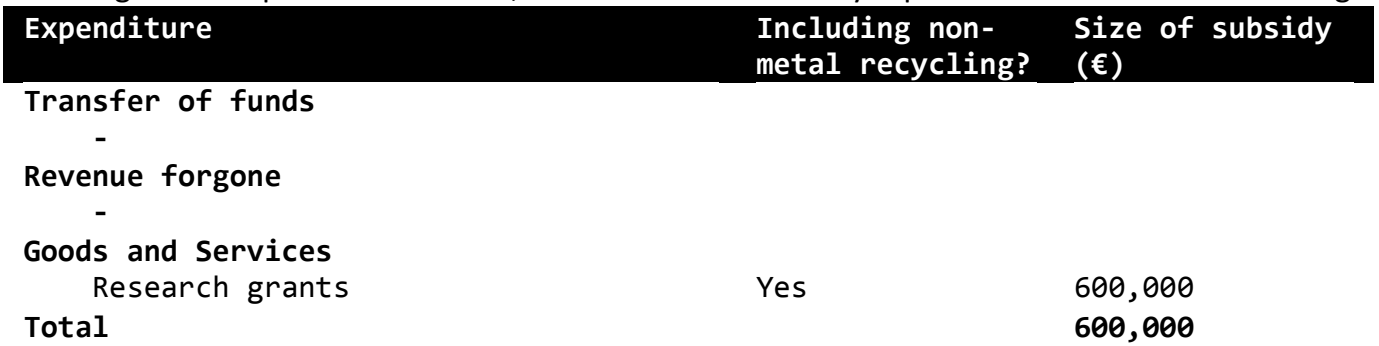

Table 2. Subsidies identified and estimated for the Swedish mining sector for the year 2010. The subcategories are presented in bold, while the actual subsidy is presented below each subcategory.

\begin{tabular}{|lll|}
\hline Expenditure & $\begin{array}{l}\text { Including non- } \\
\text { metal mining? }\end{array}$ & $\begin{array}{l}\text { Size of subsidy } \\
(€)\end{array}$ \\
Transfer of funds & & \\
- & & $12,400,000$ \\
Revenue forgone & Yes \\
$\quad$ Reduction of energy tax (gross) & Yes & $22,600,000$ \\
$\quad$ Reduction of carbon tax (gross) & & - \\
Goods and Services & - & $2,700,000$ \\
$\quad$ Remediation of mines & Yes & $1,200,000$ \\
$\quad$ Research grants & Yes & $2,000,000$ \\
$\quad$ Office of mineral information & No & $\mathbf{4 0 , 9 0 0 , 0 0 0}$ \\
$\quad$ Geological surveys & &
\end{tabular}

Subsidies in the form of tax breaks are not available for the metal recycling sector in Sweden. However, the metal mining sector has tax breaks in the form of tax exemptions as well as reductions. The use of fuel in non-transport mining processes has partly or completely been exempted from energy tax and carbon tax (SCS, 1994:1776; 2001:518). Since their introduction in $2001,100 \%$ of the energy tax and $65 \%$ of the carbon tax was deductible. Since then, the reduction of the carbon tax has increased stepwise (SCS, 2001:962; 2002:1142; 2004:223). In 2010, 100\% of the energy tax and 79\% of the carbon tax was deductible, which meant that $€ \mathbf{1 2 . 4}$ million gross and $€ \mathbf{2 2 . 6}$ million gross were repaid to the mining sector (Swedish Government, 2011). After 2011 the reduction of energy tax and carbon tax has fallen ${ }^{4}$. In addition, the mining sector is exempt from the landfill tax, i.e., a tax of $€ 49$ for every tonne of mining waste deposited (SCS, 1999:673; 2005:962), but since it is difficult to

\footnotetext{
${ }^{3}$ Only a third of the potential shortfall can be counted as a subsidy since the state is only one of three equal owners.

${ }^{4}$ After 2011, the reduction of energy tax has fallen to $84 \%$ and carbon tax to $70 \%$ (SCS, 2009:1495). But in 2013 the reduction of energy taxes increased slightly to $86 \%$ (SCS, 2009:1496). In 2015, the reduction of carbon tax will decrease to $40 \%$ (SCS, 2009:1497).
} 
determine whether the exemption is a subsidy or not the exemption will be presented in more detail in the next subchapter.

In Sweden, contaminated sites, including both abandoned scrap yards and mines, are currently identified and remediated. By the end of 2011, over 2,000 sites with high contamination levels had been remediated (SEPA, 2013). In cases where the previous owner could not be identified, the Swedish government provided an operational grant. Remediation of scrap yards has not been financed by public funds (Strauss, personal communication, 2013). However, the government funded the remediation of several mining sites. Between the years 2005-09, the government invested $€ 11$ million in the remediation of the Falun copper mine (SEPA, 2010a). In addition, the state has recently allocated $€ 1.4$ million and $€ 1.8$ million to remediate the mines Nautanen and Blaike, respectively (Strauss, personal communication, 2013). In 2010 no mining areas were remediated based on government funding.

Research grants are transferred to metal mining as well as metal recycling-related research. During the years 2006-2010, through VINNOVA the government funded the mining program

(gruvprogrammet) by $€ 5.7$ million, of which $€ 1.7$ million was paid in 2010 (VINNOVA, 2012). Another research program related to the mining sector was MinBas II, funded by the state through the Geological Survey of Sweden (SGU, 2012a) with $€ 3$ million between the years 2007-2010. In 2010 $€ 1$ million was transferred. However, this research program also included non-metals such as gravel. Between the years 2006-2012, the government through the Swedish EPA (SEPA, 2011) transferred $€$ 3.3 million to the research program sustainable waste management (hållbar avfallshantering), of which $€ \mathbf{0 . 6}$ million was allocated in 2010 (Ekvall, personal communication, 2013). However, this research program reached further than metal recycling to also embrace for example policy instruments and scenarios for sustainable waste management.

The office of mineral information (Mineralinformationskontoret) is a branch of the Geological Survey of Sweden. This office assists the prospecting industry with material from previous prospecting, which was state-funded until 1999 and thereafter private. For the year 2010, the transfer to this office by the government through SGU was $€ \mathbf{1 . 2}$ million (Jonsson, personal communication, 2013). In related years the extent of the government transfer was on a similar level ${ }^{5}$. Furthermore, SGU conducts geophysical and geochemical surveys in areas of interest to the prospecting industry, in response to the growing need for information about ores hidden deep in the bedrock. SGU has also recently inventoried and coordinated mines and minerals in Dalarna County, which should be of interest for prospectors. For the year 2010, the cost for geological surveys was $€ 1.8$ million (SGU, 2011) and for the inventory $€ \mathbf{0 . 2}$ million (SGU, 2013). After 2010, the cost of the survey and the inventory doubled ${ }^{6}$.

\subsection{The exemption from the landfill tax}

Normally, the reason for a specific tax exemption is immaterial as to whether it constitutes a subsidy (Jones \& Steenblik, 2010). Hence, the justification of the subsidization is a separate question, but before declaring an exemption a subsidy, an investigation could sometimes be required of the fine print of the rules governing in this case the exemption from the landfill tax.

The exemption of waste rock and tailings from the landfill tax is not represented in the Swedish government (2011) tax expenditures. The reason is that the European Commission (2004) has declared that the exemption of waste rock and tailings from landfill tax is not a subsidy. The background to this decision is that the main objective of the landfill tax, a reduction of waste sent to

\footnotetext{
${ }^{5}$ For the year 2008 and 2012 the transfer was $€ 1$ million and $€ 1.1$ million, respectively (Jonsson, personal communication, 2013).

${ }^{6}$ In 2012 the cost for the survey was $€ 3.8$ million and for the inventory $€ 0.4$ million (SGU, 2013).
} 
landfills, cannot be achieved, since the possibilities for process changes, alternative waste management methods and an outlet for mining waste is limited according the Swedish Government (1998). Thus, the tax is interpreted as having limited steering effect.

Residues from shredder plants of the recycling sector, generally referred to as fines ${ }^{7}$, lacking alternatives and outlets other than deposit from are, however, subject to landfill tax. So, residual fractions from primary metal production but not secondary metal production is exempt from this tax, which could be considered an advantage and thus subsidization, especially as the residues from these sectors share many material prerequisites. For example, in both cases the residue contains high levels of various forms of pollution as well as valuable metals due to inefficient technology. Hence, the efficiency could probably be improved both in the mining as well as the recycling sector, since, for example, tailings generally contain more than $10 \%$ iron (SGU, 2012b), which would reduce the amount of waste going to landfill. If the source of contamination is removed from the residual fractions of both sectors, the residues could furthermore be used as substitution for other material. One difference between the recycling sector and the mining sector, however, is that the total waste quantities of the mining sector are so large that there are not enough potential local outlets (Swedish Government, 1998). Hence, the mining sector creates such large quantities of waste that the sector not even in theory can become part of a circular economy, but is forced to partially dispose of its waste. However, to allow exemptions from the law when the generation of waste becomes larger than the potential outlet means that waste generation in itself becomes an advantage, which could be interpreted to be against the objective of the Landfill Tax Act (SCS, 1999:673) as well as many other government bills to reduce waste. Furthermore, although most nations in the European Union have made a similar interpretation of the potential steering effect of the landfill tax on mining waste, for example, a different interpretation has been made in Italy where mining waste is subject to landfill tax (Fischer et al., 2012). Thus, there are different possible interpretations of the legitimacy behind the exemption, especially when a comparable sector, the recycling sector, is paying landfill tax for residues from metal production.

If the exemption from landfill tax for the mining sector were considered governmental support, the scope changes dramatically. In 2010, 89 million tonnes of metal mining waste were generated (SEPA, 2012a), corresponding to 75\% of all waste generated in Sweden during 2010. Some 80.6 million tonnes of the metal mining waste was disposed, of which 43.9 million tonnes were deposited and 36.7 million tonnes of wet tailings were placed within embankments. Disposition of 80.6 million tonnes of metal mining waste corresponds to a shortfall of $€ \mathbf{3 , 9 4 9 . 4}$ million in 2010. Before 2010, the value of the shortfall was lower since less mining waste was disposed of ${ }^{8}$.

\subsection{Resource rent}

The mining sector does not need permission from the landowner to access minerals. For example, the Swedish right of public access (Allemansrätten) allows a prospector to take samples above ground without any permission. For more advanced prospecting, for example including drilling in the ground, a license is required by the Mining Inspectorate (Bergsstaten, 2012). For a mining permit, the activity has to receive a development consent according to the Environmental Code (SCS, 1998:808) and the Planning and Building Act (SCS, 2010:900) in court. In general, a landowner cannot stop mining concessions, but may raise objection against exploration permits, which, however, normally is

\footnotetext{
${ }^{7}$ Fines are mixed material with the common denominator that the size is less than around $1 \mathrm{~cm}$ and thus too small to be mechanically separated.

${ }^{8}$ In 2008, the revenue forgone was $€ 2,401$ million on 49 million tonnes of deposited mining waste in for example tailing ponds (SEPA, 2010b). In 2006, the shortfall was $€ 2,604$ million on 62 million tonnes of deposited mining waste (SEPA, 2008). In 2004 the shortfall was $€ 2,453$ million on 58.4 million tonnes of deposited mining waste (SEPA, 2007). Between the years 2002-2006 the landfill tax was $€ 42$ (1999:673).
} 
granted $^{9}$ on the grounds that mining activity is in the national interest (SCS, 1998:808; SR, 2010). Hence, to gain access to the metal ore, the mining sector does not need to buy land or ask for permission from the landowner.

Mining concessions granted from 2005 pay a "mineral compensation fee" of 2\%o (per thousand) of the value of the extracted minerals (SCS, 1991:45; SCS, 2005:161). Three quarters of the compensation shall be transferred to the landowner and a fourth to the government. For the year 2010, payment through the mineral compensation, both to the state and to landowners, amounted to $€ 90,828$ (SGU, 2012a) and during $2009 € 22,072$ (SGU, 2011). The government allocates the annual revenues from the mineral compensation fee to future geological research (Swedish Government, 2004). By comparison with the other end of mineral compensation, countries such as Norway, Australia and Quebec, Canada have a resource rent of 50\% (Aarsnes \& Lindgren, 2012), 22.5\% (Australian Government, 2012a) and 16\% (Quebec Government, 2013), respectively, on the profits from mining activities. Taking Australia as an example, although with a mining industry 10 times larger than Sweden in terms of added value, the revenue from the resource rent was expected to reach $€ 2$ billion during the first year (Australian Government, 2012b). Prior to 1991, the Swedish government had through the Crown share (Kronoandelen) the rights to $50 \%$ of any extractable mineral ore (SCS 1974:342).

The recycling sector gets access to secondary metals when they are defined as waste and thus disposed. In Sweden, metals are usually not collected curbside; instead citizens sort and bring scrap metal to assigned containers. Electronic waste, metal cans and other types of waste targeted for extended producer responsibility (SCS, 2005:209; SCS, 2006:1273) must in general be left at recycling stations, which are indirectly owned by the targeted producers, while other metal waste such as large metal scrap must be left at municipal recycling centers. Significant amounts of metals nevertheless end up in other waste flows, making separation and recovery difficult (Krook and Svensson, submitted; Graedel et al., 2004). It is also possible for individuals as well as businesses to sell scrap metal directly to scrap yards. Another form of collection is containers placed by the recycling agents at specific establishments, such as building sites, to capture metal waste from businesses.

Hence, regulation such as extended producer responsibility makes secondary metals available for the metal recycling sector. But there are also other regulatory instruments supporting metal recycling such as the Eco-design directive (European Parliament, 2009), which calls for limiting the number of materials used and the time for dismantling products. Furthermore, the landfill tax (SCS, 1999:673) pushes waste management towards recycling (but also waste incineration, waste prevention and reuse) by making deposition in landfills an expensive treatment method. All these instruments are certainly a support to the metal recycling sector, but difficult to quantify, just as the value of nearly free access to metals below ground is for the mining sector. However, even if access to metals is almost free, the actors extracting the metals themselves often have to pay for access. For example, metal recycling companies usually have to buy the sorted scrap metal from recycling centers, while extraction companies sometimes pay for the mining rights arranged by exploration companies.

\section{Subsidy levels compared with the importance of the sectors}

In summary, the metal mining sector was subsidized in 2010 with approximately $€ 40$ million and the metal recycling sector with approximately $€ 0.6$ million, as seen in Table 1 and 2 . If the exemption from landfill taxes is interpreted as a subsidy, the level of subsidization to the metal mining sector

\footnotetext{
${ }^{9}$ Around the year 2010 five disputes between exploration companies and landowners were tested by the Mining Inspectorate. In all cases the exploration companies was granted exploration rights (SR, 2010).
} 
increases drastically to approximately $€ 4,000$ million. Since it is difficult to determine whether the exemption from landfill tax is political support or not as shown in chapter 3.1., while the choice has a major impact on the result, two different subsidy levels for the mining sector will continuously be presented: one that includes the shortfall from the landfill tax while the other excludes the shortfall from landfill tax. This means that the subsidization of the metal mining sector was at a rate 60 or 6000 times higher than the metal recycling sector ${ }^{10}$.

The degree of subsidization must, however, be related to the magnitude and significance of the specific sector. A comparison per tonne of metal produced is arguably appropriate in the Swedish case, since both sectors are based on a similar distribution of different metals. For example, as seen in Table 3, in both cases ferrous metal production corresponds to more than $95 \%$ of the total metal production. Furthermore, the set of non-ferrous secondary metals produced in Sweden are similar to the set of primary metals produced in Sweden, including copper, zinc, nickel, gold and silver.

In Sweden more metals are produced from mines than from recycling, i.e., more metals are sent to smelters from the mining sector than from the recycling sector. In 2010, 1.8 million tonnes of secondary metals were recycled (Eurostat, 2013) while 18 million tonnes of primary metals were mined (SGU, 2012b), as seen in Table 3. Hence, the mining sector is clearly dominant as the domestic supplier of metals, producing 10 times more metals than the recycling sector in Sweden. If the Swedish subsidies are contrasted to the volume of Swedish metal production (Table 3), the subsidies per tonne of metal were $€ 0.3$ to the recycling sector and depending on perspective either $€ 2$ or 221 to the mining sector. This means that per tonne of metal produced, the mining sector, depending on perspective, was subsidized more highly at a rate either 7 or 700 times greater than the recycling sector.

Table 3. The magnitude of metal mining and recycling in Sweden and Europe (EU27) as well as the Swedish governmental subsidies towards each sector for the year 2010. The subsidy level to the mining sector is presented including and excluding the shortfall from the landfill tax. Source: BGS (2013) and Eurostat (2013).

\begin{tabular}{|c|c|c|c|c|c|c|}
\hline Metal source & $\begin{array}{l}\text { Ferrous } \\
\text { (tonne) }\end{array}$ & $\begin{array}{l}\text { Non Ferrous }{ }^{1} \\
\text { (tonne) }\end{array}$ & $\begin{array}{l}\text { Mixed } \\
\text { (tonne) }\end{array}$ & $\begin{array}{l}\text { All metals } \\
\text { (tonne) }\end{array}$ & $\begin{array}{l}\text { Subsidies } \\
\text { (€) }\end{array}$ & $\begin{array}{l}\text { Subsidies } € / \\
\text { tonne metal }\end{array}$ \\
\hline Recycling in Sweden & $1,724,500$ & 76,000 & 0 & $1,800,500$ & 600,000 & 0.3 \\
\hline Recycling in Europe & $61,380,000$ & $7,940,000$ & $9,100,000$ & $78,420,000$ & - & - \\
\hline Mining in Sweden & $17,710,000^{2}$ & 343,000 & 0 & $18,053,000$ & $\begin{array}{l}40,900,000 / \\
3990,300,000\end{array}$ & $2 / 221$ \\
\hline Mining in Europe & $19,460,000^{2}$ & $2,275,000^{3}$ & 0 & $21,735,000$ & - & - \\
\hline
\end{tabular}

${ }^{1}$ Including copper, lead, zinc, gold, silver, tin, titanium, aluminum and nickel.

${ }^{2}$ The production of primary iron has been calculated by applying SGU (2012b) assumption of iron levels of $70 \%$ in iron ore.

${ }^{3}$ The production of primary aluminum has been calculated by applying EAA (2013) assumption that the average bauxite consumption in Europe is 4.2 tonnes per tonne of aluminum.

However, the level of Swedish subsidies is relevant in the larger European context, since Swedish policies are subject to the mutual commodity agreement (European Commission, 2008) and the common market in the European Union. Within the European Union, 78.4 million tonnes of secondary metals (Eurostat, 2013) and 21.7 million tonnes of primary metals were produced in 2010 (BGS, 2013), as seen in Table 3. Hence in the EU, domestic recycling of metals is a more important source of metals than domestic ore mining, producing 3.5 times more metals than the mining sector.

\footnotetext{
${ }^{10}$ In practice, however, the differences between including and excluding the shortfall from landfill tax is not as extensive as presented above. The potential tax revenue from removing the exemption is most likely lower than the presented shortfall. For example, it is likely that less mining waste would be deposited if it was subjected landfill tax to instead be used as various types of construction materials.
} 
The value added ${ }^{11}$ of the metal-recycling sector is missing since SCB (2013a) only presents the added value for the whole recycling sector, which includes non-metal recycling. At the same time, the added value of the metal mining sector is confidential (SCB, 2013a), since there is a risk that single companies can be identified. However, the value added may be estimated based on various assumptions. Assuming that the metal mining sector share of the GDP of the whole mining sector ${ }^{12}$ in 2011 was equivalent to what it was in 2010, the added value of the metal mining sector would be $€$ 2,050 million $^{13}$ (Table 4). Assuming that the European metal recycling sector share of the turnover of the whole recycling sector in the European Union is equivalent to Swedish conditions, the added value of the metal recycling sector would be $€ 272$ million $^{14}$ (Table 4).

Table 4. A comparison of the Swedish metal recycling and metal mining sector's share of GDP in relation to tonnes of metal produced in 2010.

\section{Metal source Value added $(€)$ Share of total GDP Value added $€ /$ tonne metal}

\begin{tabular}{|l|l|l|l|}
\hline Recycling & $272,000,000$ & $0.07 \%$ & 151 \\
\hline Mining & $2,050,000,000$ & $0.54 \%$ & 114 \\
\hline Total GDP & $377,549,000,000$ & $100 \%$ & \\
\hline
\end{tabular}

The metal mining sector's share of Swedish GDP in 2010 was $0.54 \%$, while the metal recycling sector's share was $0.07 \%$ (Table 4 ), which means that the mining sector's total value added was about 8 times higher. However, considering that both sectors produce a similar distribution of metals, the value added can be contrasted to per produced tonne metal, which results in a $30 \%$ higher value added per tonne for the recycling sector than for the mining sector (Table 4). This means that per tonne of metal, secondary production appears to add more value and national growth than primary production. The comparison of GDP is nevertheless uncertain, since the isolated data for the sectors is based on assumptions. However, other economic indicators, such as the export value of primary and secondary metals, also demonstrate a similar pattern. The export value of primary metals is about three times higher than secondary metals (Table 5). But per tonne of metal produced, the recycling sector adds a significantly higher export value than the mining sector.

Table 5. The value of exporting primary and secondary metals from Sweden, compared with the total value of Swedish exports in 2010. Presented in millions of $€(M €)$. Source: SCB, 2013b.

\begin{tabular}{|l|l|l|} 
& Export (M€) & \multicolumn{1}{|l|}{ Share of total export } \\
\hline Primary metals $^{\mathbf{1}}$ & 2,419 & $1.9 \%$ \\
\hline Secondary metals & 692 & $0.5 \%$ \\
\hline Total Export & 128,752 & $100 \%$ \\
\hline
\end{tabular}

${ }^{1}$ Including export of iron, copper, nickel, aluminum, other non-precious metals. Precious metals are excluded since the value is presented as a mix of primary and secondary metals.

${ }^{2}$ Including export of iron, steel and other non-precious metal scrap. Precious metals are excluded since the value is presented as a mix of primary and secondary metals.

The metal mining sector is subsidized by $€ 40.9$ million or $€ 3990$ million if the shortfall from the landfill tax is included, while the same sector creates an added value of $€ 2,050$ million (Table 4). Hence, if the shortfall is excluded, the subsidy level is $2 \%$ of value added. But on the other hand, if

\footnotetext{
11 The value added is the gross output minus the intermediate consumption of goods and services during production.

12 Includes all kinds of mineral mining, e.g. metals as well as lime, gravel and sand (SNI code: 071-081).

${ }^{13}$ The added value of the whole mining sector, including non-metal recovery, in 2010 was $€ 2,808$ million (SCB, 2013a). In 2011, $73 \%$ of the value added by the whole mining sector came from the metal mining industry (Swedish Government, 2013).

${ }^{14}$ For the whole recycling sector, including non-metal recovery (SNI code: 383), the value added in 2010 was $€$ 340 million (SCB, 2013a). The EEA (2011) has shown that during the years 2004-09 the metal recycling sector accounted for at least $80 \%$ of the total turnover in the recycling sector within the European Union.
} 
the shortfall from the landfill tax is included, the subsidies are almost twice as high as the added value. The recycling sector creates an added value of $€ 272$ million and is subsidized by $€ 0.6$ million, which represents approximately $0.3 \%$ of value added. The correlation between Swedish subsidies, production and added value of the metal recycling and metal mining sector can be viewed in Table 6 .

Table 6. A comparison of the Swedish metal recycling and metal mining sector's share of the subsidies, production and added value of the total metal sector in 2010.

\begin{tabular}{|l|l|l|l|l|}
\hline \multicolumn{2}{|l|}{ Metal subsidies $^{\text {a }}$} & Metal subsidies & Metal production & Metal added value \\
\hline Metal mining sector & $99.9998 \%$ & $98.5 \%$ & $90.9 \%$ & $88.3 \%$ \\
\hline Metal recycling sector & $0.0002 \%$ & $1.5 \%$ & $9.1 \%$ & $11.7 \%$ \\
\hline Total metal sector & $100 \%$ & $100 \%$ & $100 \%$ & $100 \%$ \\
\hline
\end{tabular}

a Including the shortfall from the landfill tax

${ }^{b}$ Excluding the shortfall from the landfill tax

\section{Discussion}

To determine whether the exemption from landfill tax is political support is not only an ambiguous choice with arguments both for and against with a major impact on the result of this study, but a choice with potential societal consequences. For example, if the exemption of mining waste from the landfill tax is considered a subsidy, it means that the mining sector is subsidized more than twice as much as the sector's value added and much higher than other commodity sectors. The Swedish EPA (SEPA, 2012b) estimated that the environmentally harmful subsidies to the Swedish energy and transport sectors in 2010 were $€ 2.4$ billion and $€ 2.8$ billion, corresponding to approximately $25 \%{ }^{15}$ and $33 \%{ }^{16}$ of the added value, respectively. In addition, the Swedish Board of Agriculture (2013) estimated that the agriculture sector in Sweden received $€ 1.1$ billion in $2010^{17}$, corresponding to approximately $37 \%{ }^{18}$ of the added value. On the other hand, if the exemption of mining waste from the landfill tax is not considered a subsidy, the subsidization of the mining sector is $2 \%$ of the value added from the same sector, which is considerable smaller than many other industrial sectors. So depending on one's perspective, metal mining in Sweden is either one of the most or one of the least subsidized commodity sectors of the economy. Either way the, metal-recycling sector is supported less.

The same ambiguity occurs when the result, $€ 4$ billion including the shortfall from the landfill tax or around $€ 40$ million excluding the shortfall, is compared with other subsidy analysis of the domestic metal sector. By analyzing primary tax concessions based on the revenue forgone method, Grundnoff (2012) estimated that the Australian mining sector was subsidized by $€ 2.9$ billion annually. Grundnoff (2012) did not include the exemption from landfill tax as a subsidy but nevertheless reached an extensive result since extraction of all minerals such as metals, clay, oil and gas was included at the same time as the Australian mining sector is many times larger than the Swedish one in terms of value added. The Australian mining sector (including the extraction of all minerals) and the metal mining sector added value in 2009-10 (ended 30 June) was $€ 57$ billion and $€ 24$ billion (ABS, 2012), respectively.

Considering that the definition and what is categorized as a subsidy has such a decisive impact on the final result, assessments of subsidy levels easily slip into controversies about what should count as a

\footnotetext{
${ }^{15}$ The added value of the SNI code "35: Electric, gas and heating plants" was $€ 9.5$ billion in 2010 (SCB, $2013 a$ ).

${ }^{16}$ The added value of the SNI codes "49: Land transport, 50 shipping and 51 airlines" was $€ 8.5$ billion in 2010 (SCB, 2013a).

${ }^{17}$ These estimates are not completely comparable since only direct transfers from the EU and the Swedish government were included in the analysis of the agriculture sector and direct transfers and tax concessions were included in the analysis of the transport and energy sectors.

${ }^{18}$ The added value of the SNI code "1: Farms and related service activities" was $€ 3$ billion in 2010 (SCB, 2013a)
} 
subsidy, rather than discussion about policies and subsidy levels. For example, the Grundnoff (2012) report started a debate in Australia about the level of mining subsidization. Davidson (2012) formulated the opposing view: "the [Australian] mining industry is not the beneficiary of special measures that substantially reduce its tax burden...[or] large amounts of government subsidy." However, the advantage of symmetrically comparing two similar sectors, such as this study, is that the relationship between the two sectors is in focus rather than one single sector's subsidy level. Certainly, the definition of subsidy may favor or disfavor one of the sectors. But, at least in this study, the mining sector appears to be the beneficiary of a higher rate of subsidies, regardless of the definition of subsidy. For example, if this study counted only research grants, the mining sector would be subsidized by $€ 2.7$ million and the recycling sector by $€ 0.6$ million.

Although secondary metal production seems to add a greater value per tonne of metal than primary metal production, there is a clear political commitment in Sweden for the mining sector symbolized by a statement from Fredrik Reinfeldt, the prime minister of Sweden: "Mines are for Sweden what oil is for Norway" (TT, 2012). The uneven distribution of subsidies between the metal recycling and mining sector will at the same time increase in the coming years. In the Swedish mineral strategy (Swedish Government, 2013) increased metal recycling and mining are both emphasized, while direct support is primarily formulated for the metal mining sector. Current objectives include: facilitating the construction of dwellings in mining communities by changing the governmental guarantees; reducing the process time for mining permissions by increasing the grants to licensing authorities; investing $€ 400$ million in mining-related infrastructure; and providing $€ 23$ million for research related to mining, minerals and steel.

\subsection{The future metal supply}

Future metal demand, which is expected to increase (e.g. Backman, 2008; UNEP, 2013), could be covered by extending the already dominant primary production of metals further by extracting metals from even lower-grade ores or the exploration of new potential reserves, for example in the deep sea. However, learning how to cost-efficiently prospect and extract metals from such still unconventional primary reserves will require extensive investments in knowledge and technology development as well as in new facilities and infrastructure (Glasby, 2000; Swedish Government, 2013). Given the current institutional conditions for primary production, demonstrated in this paper by various subsidies, and the gradually increasing political support, represented for example in the Swedish mineral strategy, such an approach still seems to be the main chosen path to meet future demand.

Among other things, this priority derives from the perception of recycling being limited only to the relatively small amounts of metals occurring in annually generated waste streams (Swedish Government, 2013; Lööf, 2013). However, recent research shows that there is large potential to increase secondary metal production, which means that an alternative or complementary approach to meet future demand could be increased metal recycling. First, the recovery of metals occurring in annual waste flows is currently ineffective. For example, for some base metals (e.g. iron, copper, chromium, nickel and zinc) and some highly valuable metals such as gold and platinum, the recycling rates in industrial countries are at least over $50 \%$ while for more than a third of all metal types like rare earth metals the recycling is negligible ${ }^{19}$ (UNEP, 2011). Second, due to the ongoing relocation process of metals from below to above-ground, i.e., the geological shift (Johansson, 2013), the metal stocks in the technosphere are gradually growing (UNEP, 2010). For instance, the global in-use stock of copper has grown significantly and corresponds currently to $50 \%$ of the reserves remaining in known virgin ores (Johansson et al., 2013). Third, in addition to the metals in-use, metals accumulate in other technospheric stocks, which are directly available, for example in tailing ponds, slag heaps,

\footnotetext{
${ }^{19}$ The fact that only some metals are recovered from the waste streams also means that non-recycled metals may follow and become a contamination in the recovered metal.
} 
and landfills. Furthermore, large shares of obsolete metal waste do not reach waste collection but are abandoned, for example in attics (Saphores et al., 2010) and underground (Krook et al., 2011; Wallsten et al., 2013). The overall metal content in these inactive stocks, again taking copper as an example, is comparable to the current in-use stock of copper, i.e., 330 million tonnes (Kapur, 2006). Thus, collectively the amount of copper in the technosphere is comparably to the reserves in the Earth's crust. These stocks could be extracted and thus significantly increase the inflow of secondary metals (Ayres, 1999).

Similar to the challenges facing an extended primary metal sector, a significantly increased recycling sector relies on the exploration of low-grade or unconventional metal sources. One difference between secondary and primary production, however, is that the established market conditions for metal extraction are adapted to primary production. For instance, low taxes on energy favor energyintensive primary production while the labor-intensive secondary production is disadvantaged by high taxes on labor (Ayres, 1997). Furthermore, as demonstrated in this paper, primary production has, compared to secondary production, for example, lower taxes, tax exemptions, higher research funds and governmental support to locate metals. This means, for example, that if metals are extracted from a secondary metal stock, such as a landfill, rather than the Earth crust, re-deposition of residues are subject to landfill tax, which makes such operations less profitable (Johansson et al., 2012). Therefore, if increased recycling is desired, which is reflected in several policy documents (European Commission, 2008; Swedish Government, 2013), secondary metal production also needs to become more interesting and thus favorable for commercial actors.

However, this does not necessarily mean that the subsidies for primary production should be removed, since such measures may bring unwanted side effects. For example, if the exemption from landfill tax on mining waste is removed, a higher proportion of the mining waste will probably be used as construction material, for example in roads. The consequence of this is that the metals not separated from the rock, ending up in tailings, will be dispersed in various constructions and thus less accessible for future extraction. Reprocessing of old piles of mining waste is actually not unusual (e.g. Greadel et al., 2004; Gunnarsson and Gunnarsson, 2007). From a metal supply perspective, it may prove more reasonable to exempt residues from all forms of metal production from landfill tax rather than removing the exemption of mining waste.

As a result of requests from multilateral organizations such as the UN, EU and OCED, the Swedish authorities (e.g. SEPA, 1997; SCB, 2000), like many other countries (OECD, 1998) have been analyzing environmentally harmful subsidies since the late 1990s. Initially, only environmentally related tax concessions were mapped (e.g. SCB, 2000), but direct transfer is increasingly emphasized (e.g. SEPA, $2012 b)$. However, if the concept of subsidy were to be defined even more broadly to also include, for example, research grants and uncollected resource rents, the collection of information for policy analysis would become easier and the estimates more accurate and comprehensive. Furthermore, there are subsidies that are not harmful to the environment but still favor a particular sector. This study has also recognized the need to present subsidies and other economic indicators in detailed subgroups. Economic indicators are today presented for wider groups such as the entire mining sector as well as the recycling sector and not divided according to resource type, i.e., oil, clay and metals. Another problem is that various agencies compile information on sectoral subsidies (e.g. SCB, 2010; SEPA, 2012b; Swedish Board of Agriculture, 2013), which results in different definitions of the term subsidy and asymmetry in the comparisons between the sectors. Hence, to facilitate the comparison of sectors, a single authority should probably collect subsidy data for all sectors.

\section{Conclusion}

It is difficult to generalize from the Swedish case. For example, some countries lack formal recycling systems, although different configurations of informal waste pickers tend to take the responsibility of 
recycling secondary metals in those countries. Furthermore, in some countries primary metals are generally extracted by informal small-scale miners. Hence, the nature of secondary and primary metal producers varies among countries and thus probably also the level of political commitment and support. The relation between secondary and primary metal production therefore needs more research, both in a domestic and international context, not least since the concept of subsidy can be defined and delimited in so many ways. It would, for example, be interesting to see in countries and at the EU level where the situation is reversed, i.e., where recycling is the major source of domestic metal, if the level of subsidization is different.

What is a fair level of subsidies between the metal recycling sector and the metal mining sector depends on many different aspects such as policy objectives and the sectoral need of support to emerge. The extent of the need for subsidization is a dimension which has not been the focus of this study and could be a natural continuation. In the end, however, the level of subsidies is not only a rational question, but also a question of what values are considered to be important, for example either rural development as a result of the opening of new mines or reduced energy demand as a consequence of recycling. These choices are political and should be a democratic decision. This report creates an opening, however, for further policy discussion by uncovering the priorities of the Swedish government, demonstrating in total and per tonne of metal produced that the mining sector receives higher subsidies despite (or maybe because of) a lower added value produced per tonne than the recycling sector. But the level of subsidy is in practice not only determined by values and policies but also for example by traditions and influences from powerful sectors. Another avenue for future research could thus be to analyze subsidy levels over time in order to understand what shaped them.

\section{Acknowledgements}

Financial support was provided by the Swedish Innovation Agency, VINNOVA. Naturvårdsverket, SGU and SCB have contributed valuable background data. Ivetta Gerasimchuk and Maja Cederlund contributed valuable support and comments.

\section{References}

Aarsnes, F., Lindgren, P., 2012. Fossil Fuels - At What Cost? Government support for upstream oil and gas activities in Norway. Global Subsidies Initiative. Geneva, Switzerland.

ABS, 2012. Mining industry. Economic contribution. Year Book Australia, 2012. Australian Bureau of Statistics. Available online:

http://www.abs.gov.au/ausstats/abs@.nsf/Lookup/by\%20Subject/1301.0 2012 Main\%20Featur es Mining\%20Industry 150 [access: 2013-05-08]

Anderson, K., Martin, W., 2005. Agriculture Market Access: The Key to Doha Success. World Bank. Trade note 23. Available online: http://siteresources.worldbank.org/INTRANETTRADE/Resources/Pubs/TradeNote23.pdf [access: 2013-05-08]

Australian Government, 2012a. Minerals Resource Rent Tax Act 2012. ComLaw Authoritative Act C2012A00013. Australia.

Australian Government, 2012b. Budget 2012-2013. Budget Paper No. 1: Budget Strategy and Outlook 2012-13. Australia

Ayres, R., 1997. Metals recycling: economic and environmental implications. Resources, Conservation and Recycling 21 (3): 145-173.

Ayres, R., 1999. The second law, the fourth law, recycling, and limits to growth. Ecological Economics 29: 473-484.

Backman, CM., 2008. Global supply and demand of metals in the future. J. Toxicol Environ Health A 71(18): 1244-53. 
Bergsstaten, 2012. Bra att veta för markägare/Useful information for landowners. Available online: http://www.bergsstaten.se/info/mark.htm [access: 2013-05-01]

Bridge, G., 2014. Resource geographies II: the resource-state nexus. Progress in Human Geography 38 (1): 118-130.

Bruce, N., 1990. Measuring industrial subsidies: Some conceptual issues. OECD Department of Economics and Statistics. Paris: OECD.

BGS, 2013. World Mineral Production 2006-2011. British Geological Survey. United Kingdom.

Clements, B., Coady, D., Fabrizio, S., Gupta, S., Alleyne, T., Sdalevich, C., 2013. Energy Subsidy Reform: Lessons and Implications. Washington, DC: International Monetary Fund.

Davidson, S., 2012. Mining Taxes and Subsidies: Official evidence. Minerals Council of Australia. Available online:

http://www.minerals.org.au/file upload/files/publications/mca backgrounder FINAL.pdf [access: 2013-05-08]

EAA, 2013. Aluminium - Production process. European Aluminium Association. Available online: http://www.alueurope.eu/about-aluminium/production-process/ [access: 2013-05-08]

EEA, 2011. Earnings, jobs and innovation: the role of recycling in a green economy. European Environment Agency. No 8/2011. EEA publication; Denmark.

Ekvall, T. 2013. Personal communication through email with Ekvall at IVL.

EMJ, 1999. Annual project survey. Engineering and Mining Journal 200(1):22-25.

Elshkaki, A., van der Voet, E., van Holderbeke M., Timmermans, M., 2004. The environmental and economic consequences of the developments of lead stocks in the Dutch economic system. Resources, Conservation and Recycling 42: $133-154$.

European Commission, 2004. Förlängning och ändring av stödordningen för avfallsskatt/Extension and modification of the scheme for waste tax. NN 161/2003. Brussels.

European Commission, 2008. The raw materials initiative - meeting our critical needs for growth and jobs in Europe. Communication, COM (2008) 699. Brussels.

European Parliament, 2009. Ecodesign directive 2009/125/EC. Official Journal of the European Union 285: $10-35$

Eurostat, 2013. Environmental Data Centre on Waste. Database. Available online: http://epp.eurostat.ec.europa.eu/portal/page/portal/waste/data/database [access: 2013-05-08]

Fischer, C., Lehner, M., McKinnon, D.L., 2012. Overview of the use of landfill taxes in Europe. ETC/SCP. Copenhangen, Denmark.

Gerasimchuk, I., 2012. Fossil Fuels - At What Cost? Government support for upstream oil and gas activities in Russia. Global Subsidies Initiative. Geneva, Switzerland.

Gordon, R.B., Bertram, M., Graedel, T.E., 2006. Metal stocks and sustainability. PNAS 103 (5): 12091214.

Glasby, G.P., 2000. Lessons learned from deep-sea mining. Science 289 (5479): 551-553.

Grudnoff, M., 2012. Pouring Fuel on the Fire: The nature and extent of Federal Government subsidies to the mining industry. The Australia Institute. Policy Brief No. 38. Australia.

Graedel, T.E., van Beers, D., Bertram, M., Fuse, K., Gordon, R.B., Gritsinin A., Kapur, A., Klee, R., Lifset, R., Memon, L., Rechberger, H., Spatari, S., Vexler, D., 2004. The multilevel cycle of anthropogenic copper. Environmental Science and Technology 38: 1253-1261.

GSI, 2010. Relative Subsidies to Energy Sources: GSI estimates. Global Subsidies Initiative. Geneva, Switzerland.

Gunnarsson, M., Gunnarsson E., 2007. Zinkgeuvan Mining 1857-2007. Bild och Kultur AB, Skyllberg.

Halada, K., Ijima, K., Shimada, M., Katagiri, N., 2009. A possibility of urban mining in Japan. J. of Japan Institute of Metals 73: 151-160.

IEA, OPEC, OECD, World Bank, 2010. Analysis of the scope of energy subsidies and suggestions for the G-20 initiative. Available online: http://www.oecd.org/env/45575666.pdf [access: 2013-05-08]

IEA, 2011. World Energy Outlook. International Energy Agency. ISBN 978-92-64-12413-4. Paris, France. 
IEEP, 2012. Study supporting the phasing out of environmentally harmful subsidies. The Institute for European Environmental Policy. Available online:

http://ec.europa.eu/environment/enveco/taxation/pdf/report phasing out env harmful subsidies.p df [access: 2013-05-08]

IFPRI, 2003. How much does it hurt? The impact of agricultural trade policies on developing countries. International Food Policy Research Institute. Available online: http://www.ifpri.org/sites/default/files/pubs/media/trade/trade.pdf [access: 2013-05-08]

Johansson, N., 2011. Rekordresultat för LKAB/Record results for LKAB. NSD 2011-02-15. Available online: http://www.nsd.se/nyheter/artikel.aspx?Articleld=5975582 [access: 2013-05-08].

Johansson, N., Krook, J., Eklund, M., 2012. Transforming dumps into gold mines. Experiences from Swedish case studies. Environmental Innovation and Societal Transitions 5: 33-48.

Johansson, N., Krook, J., Eklund, M., Berglund, B. 2013. An Integrated Review of Concepts for Mining the Technosphere: Towards a New Taxonomy. Journal of Cleaner Production 55: 35-44.

Johansson, N., 2013. Why don't we mine the landfills? Licentiate thesis. Linköping University, Sweden.

Jones, J., Steenblik, R., 2010. Subsidy Estimation: A survey of current practice. The Global Subsidies Initiative. Geneva, Switzerland.

Jonsson, E., 2013. Personal communication through telephone with Jonsson at SGU.

Kapur, A., 2006 The future of the red metal: discards, energy, water, residues, and depletion. Progress in Industrial Ecology - An International Journal 3 (3): 209-236.

Kleijn, D., Berendse, F., Smit, R., Gilissen, N., 2001. Agri-environment schemes do not effectively protect biodiversity in Dutch agricultural landscapes. Nature 413: $723-725$.

Krook, J., Svensson, N., submitted. Potential metal resources in waste incineration ash deposits. Waste Management, Special Issue Urban Mining.

Krook, J., Carlsson, A., Eklund, M., Frändegård, P., Svensson, N., 2011. Urban mining: hibernating copper stocks in local power grids. Journal of Cleaner Production, 19(9), 1052-1056.

Lichtensteiger, T., 2002. The Petrologic Evaluation. Berlin; Springer-Verlag.

Lin, H.C., 1996. Coordinating bilateral export subsidies under monopolistic competition. Journal of International Trade and Economic Development 5 (3): 319-39.

Lööf, A., 2013. Anförande 59 av Näringsministern/Statement 59 from the Minister of Industry. Parliamentary Protocol 2013/14: 8. Available online: http://www.riksdagen.se/sv/DokumentLagar/Kammaren/Protokoll/ H1098/ [access: 2014-01-28]

Milazzo, M., 1998. Subsidies in World Fisheries. World Bank Technical Paper No. 406. Washington, DC, USA.

Müller, D., Wang, T., Duval, B., Graedel, TE., 2006. Exploring the engine of anthropogenic iron cycles. PNAS 103: 16111-16116.

OECD, 1998. Statistics on ECO taxes: Progress report, DAFFE/CFA/CT (98) 19. OECD Publications, Paris.

OECD, 2009. The Economics of Climate Change Mitigation: Policies and Options for Global Action Beyond 2012. OECD Publications, Paris.

OECD, 2010a. Measuring Support to Energy - Version 1.0. OECD Publications, Paris.

OECD, 2010b. Tax Expenditures in OECD Countries. OECD Publications, Paris.

Pieters, J., 1997. Subsidies and the Environment: on How Subsidies and Tax Incentives May Affect Production Decisions and the Environment. Paper for the UN Fourth Expert Group. Meeting on Financial Issues of Agenda 21, January 8-10 1997, Santiago, Chile.

Quebec Government, 2013. Mining Tax Act. chapter I-04. Quebec, Canada.

Riedy, C., 2003. Subsidies that Encourage Fossil Fuel Use in Australia. Working Paper CR2003/01. Institute for Sustainable Futures, University of Technology, Sydney, Australia.

Saphores, J-D.M., Nixon, H., Ogunseitan, O.A., Shapiro, A.A., 2009. How much e-waste is there in US basements and attics? Results from a national survey. Journal of Environmental Management 90 (11): 3322-3331. 
SCB, 2000. Miljöskatter och miljöskadliga subventioner/Environmental taxes and environmentally harmful subsidies. Statistics Sweden. SCB rapport 2000:3. ISSN 1403-1337. Stockholm, Sweden.

SCB, 2010. Miljörelaterade skatter, subventioner och utsläppsrätter/Environmental taxes, subsidies and emissions allowances. SCB Rapport 2010:2. ISSN 1654-6822. Stockholm, Sweden.

SCB, 2013a. Basfakta företag enligt Företagens ekonomi efter näringsgren SNI 2007. År $2000-$ 2011/Business Statistics by industry SNI 2007. Year 2000-2011. Database. Available online:

http://www.scb.se/Pages/SSD/SSD SelectVariables 340487.aspx?px tableid=ssd extern\%3aBasf aktaFEngs07\&rxid=083b45da-95c2-48ab-ad39-1dd3fa6f8eef [access: 2013-05-08]

SCB, 2013b. Varuimport och varuexport efter produktgrupp SPIN2007/Imports and exports by product group SPIN2007. Database. Available online: http://www.ssd.scb.se/databaser/makro/start.asp [access: 2013-05-08]

Schwartz, G., Clements, B., 1999. Government subsidies. Journal of Economic Surveys 13 (2): 119148.

SCS, 1974:342. Gruvlagen/Mining Act. Swedish Code of Statutes. Sweden.

SCS, 1991:45. Minerallagen/Mineral Act.

SCS, 1994:1776. Lag om skatt på energi/Act on energy tax.

SCS, 1998:808. Miljöbalken/Environmental Code.

SCS, 1999:673. Lag om skatt på avfall/Act on waste tax.

SCS, 2001:518. Lag om ändring i lagen (1994:1776) om skatt på energi/Change in the Act on energy tax.

SCS, 2001:962. Lag om ändring i lagen (1994:1776) om skatt på energi/Change in the Act on energy tax.

SCS, 2002:1142. Lag om ändring i lagen (1994:1776) om skatt på energi/Change in the Act on energy tax.

SCS, 2004:223. Lag om ändring i lagen (1994:1776) om skatt på energi/Change in the Act on energy tax.

SCS, 2005:161. Lag om ändring i minerallagen (1991:45)/Change in the Mineral Act.

SCS, 2005:209. Förordning om producentansvar för elektriska och elektroniska produkter/Ordinance on producer responsibility for WEEE.

SCS, 2005:962. Lag om ändring i lagen (1999:673) om skatt på avfall/Change in the Act on waste tax.

SCS, 2006:1273. Förordning om producentansvar för förpackningar/Producer responsibility for packaging.

SCS, 2009:1495. Lag om ändring i lagen (1994:1776) om skatt på energi/Change in the Act on energy tax.

SCS, 2009:1496. Lag om ändring i lagen (1994:1776) om skatt på energi/Change in the Act on energy tax.

SCS, 2009:1497. Lag om ändring i lagen (1994:1776) om skatt på energi/Change in the Act on energy tax.

SCS, 2010:900. Plan- och bygglagen/Planning and Building Act.

SEPA, 1997. Ett urval av statliga subventioner som kan antas motverka en ekologiskt hållbar utveckling/A selection of government subsidies which are likely to counter ecologically sustainable development. Government commission. Swedish Environment Protection Agency: Naturvårdsverket. Sweden.

SEPA, 2007. Avfall I Sverige 2004/Waste in Sweden 2004. Naturvårdsverket. CM Gruppen AB; Bromma.

SEPA, 2008. Avfall I Sverige 2006/Waste in Sweden 2006. Naturvårdsverket. CM Gruppen AB; Bromma.

SEPA, 2010a. Eftterbehandling gruvavfall i Falun 1992-2008/Remediation of tailings in Falun. Naturvårdsverket. CM Gruppen AB; Bromma

SEPA, 2010b. Avfall I Sverige 2008/Waste in Sweden 2008. Naturvårdsverket. CM Gruppen AB; Bromma.

SEPA, 2011. Årsredovisning 2010/Annual Report 2010. Naturvårdsverket. CM Gruppen AB; Bromma 
SEPA, 2012a. Avfall I Sverige 2010/Waste in Sweden 2010. Naturvårdsverket. CM Gruppen AB; Bromma.

SEPA, 2012b. Potentiellt miljöskadliga subventioner/Potentially environmentally harmful subsidies. Rapport 6455. Available online: www.naturvardsverket.se/Documents/publikationer6400/978-91620-6455-6.pdf [access: 2013-05-08]

SEPA, 2013. De flesta förorenade områdena är kända/The majority of the contaminated sites are known. Naturvårdsverket. Available online: http://www.naturvardsverket.se/Sa-marmiljon/Mark/Fororenade-omraden/ [access: 2013-05-01]

SGU, 2011. Verksamhetsberättelse och årsredovisning 2010/Annual Report 2010. The Geological Survey of Sweden: Sveriges Geologiska Undersökning. KPH Trycksaksbolaget AB; Uppsala.

SGU, 2012a Verksamhetsberättelse och årsredovisning 2012/Annual Report 2012. Sveriges geologiska undersökning. Elanders Tryckeri: Mölnlycke.

SGU,2012b. Bergverksstatistik 2011/Statistics of the Swedish Mining Industry 2011. Imprima Visuell Kommunikation AB; Solna.

SGU, 2013. Verksamhetsberättelse och årsredovisning 2012/Annual Report 2012. Sveriges geologiska undersökning. Elanders Tryckeri: Mölnlycke.

SIRS, 2013. Arbetsgivaravgifter/Employment tax. The Swedish Internal Revenue Service: Skatteverket. Available online: http://www.skatteverket.se/foretagorganisationer/arbetsgivare/socialavgifter/arbetsgivaravgifter .4.233f91f71260075abe8800020817.html [access: 2013-05-08]

Spatari, S., Bertram, M, Gordon R.B, Henderson, K., Graedel, T.E., 2005. Twentieth-century copper stocks and flows in North America: A dynamic analysis. Ecological Economics 54: 37 - 51.

SR, 2010. Svårt för markägare att stoppa gruvor/ Difficult for landowners to stop mines. Swedish Radio 2010-08-20. Available online: http://sverigesradio.se/sida/artikel.aspx?programid=83\&artikel=3935738 [access: $2014-03-31$ ]

Steenblik, R.P., 2002. Subsidy measurement and classification: Developing a common framework. Environmentally Harmful Subsidies: Policy Issues and Challenges. OECD Publications, Paris, 101141

Sterner, T., 2007. Fuel Taxes: An Important Instrument for Climate Policy. Energy Policy 35: 31943202.

Strauss, C.M., 2013. Personal communication through email with Strauss at the Swedish EPA.

SVD, 2013. LKAB och Peab går in i Northland Resources/LKAB and Peab enters Northland Resources. SVD 2013-05-29. Available online: http://www.svd.se/naringsliv/lkab-uppges-ga-in-i-northlandresources 8221946.svd [access: 2014-01-28]

Swedish Board of Agriculture, 2013. Jordbruksstöden i EAA-kalkylen/Agricultural support in EAA calculation. Jordbruksverket. Sweden.

Swedish Government, 1995. Proposition from the government to the parliament. Proposition 1995/96:222.

Swedish Government, 1998. Lag om skatt på avfall/Act on waste tax. Proposition from the government to the parliament. Proposition 1998/99: 84. Sweden.

Swedish Government, 2004. Ändringar i minerallagen/Changes in the Mineral Act. Proposition from the government to the parliament. Proposition 2004/05:40

Swedish Government, 2011. Redovisning av skatteutgifter 2011/Tax expenditures in 2011. Communication from the government to the parliament. Skrivelse 2010/2011:108.

Swedish Government, 2013. Sveriges mineralstrategi/The Swedish mineral strategy. Elanders; Mölnlycke.

Söderhielm, J., 2013. Personal communication through telephone with Söderhielm at the office for mineral information.

TT, 2012. Satsning på gruvor i budgeten/Budget investment in mining. SVD näringsliv. Available online: http://www.svd.se/naringsliv/branscher/industri-och-fordon/satsning-pa-gruvor-ibudgeten 7474112.svd [access: 2013-05-08]

Tullock, G., 1975. The Transitional Gains Trap. The Bell Journal of Economics 6 (2): 671-678. 
UNEP, 2010. Metal stocks in society. International Panel for Sustainable Resource Management, Working Group on the Global Metal Flows. United Nation Environment Programme. Nairobi, Kenya.

UNEP, 2011. Metal Recycling rates. International Panel for Sustainable Resource Management, Working Group on the Global Metal Flows. Nairobi, Kenya.

UNEP, 2013. Environmental Risks and Challenges of Anthropogenic Metals Flows and Cycles. International Panel for Sustainable Resource Management, Working Group on the Global Metal Flows. Nairobi, Kenya.

Unruh, G., 2000. Understanding carbon lock-in. Energy Policy 28 (12): 817-830.

VINNOVA, 2012. Utvärdering av Strategiskt gruvforskningsprogram/Evaluation of the Swedish National Research Programme or the Mining Industry. Available online: http://www.vinnova.se/upload/EPiStorePDF/vr-12-01.pdf [access: 2013-05-01]

Wallsten, B., Carlsson, A., Frändegård, P., Krook, J., Svanström, S., 2013. To prospect an urban mine assessing the metal recovery potential of infrastructure "cold spots" in Norrköping, Sweden. Journal of Cleaner Production 55: 103-111.

WRI, 2007. Agricultural subsidies, poverty and the environment: supporting a domestic reform agenda in developing countries. World Resources Institute. Policy Note No. 1. Available online: http://pdf.wri.org/aspe domestic reform.pdf [access: 2013-05-08]

WTO, 1994. Agreement on Subsidies and Countervailing Measures (ASCM). World Trade Organization. Available online: http://www.wto.org/english/docs_e/legal_e/24-scm_01_e.htm [access: 2013-05-08]

Yeo, M.S., Partner, S., Johnsson, L.L.P., 2010. Natural Resource Subsidies. Discussion forum: World Trade Report 2010. Trade in Natural Resources: Challenges in Global Governance. Available online: http://www.wto.org/english/res e/publications e/wtr10 forum e/wtr10 yeo e.htm [access: 2013-05-08] 